\title{
The Impact Of Liberalization On Foreign Direct Investment In The Slovak Republic
}

Sivakumar Venkataramany, Ashland University, USA

Paul A. Miklovich, Ashland University, USA

\begin{abstract}
Czechoslovakia became a "non-nation" in January 1993. The creation of the Czech and Slovak Republics resulted in two unique and distinct societies which moved in different economic directions. While the Czech Republic prospered within the first six years, the same could not be said for Slovakia. For the first six years, Slovakia's economic growth was stifled due to factors of economic and financial repression. As a result of the political changes, financial liberalization began to emerge and, as a result, economic progress. As pronounced were the effects of repression, so too were the effects of liberalization. To truly understand the impact upon the society, the change must be viewed from the viewpoint of foreign direct investment. The factors which limited FDI due to their repressive nature, were now being replaced with factors that encouraged and expanded FDI within the Slovak nation. As a result of a complete turnaround transformation, Slovakia is now on a course to sustain and expand economic development through increased FDI. To understand the overall transformation that occurred within the Slovak Republic, one needs to define the factors that create financial repression and the liberalization factors that move an economy in a different direction. The determinants of foreign direct investment (FDI) must be examined along with the transition from repression to liberalization.
\end{abstract}

Keywords: FDI, Slovakia, Financial Repression, Liberalization

\section{INTRODUCTION}

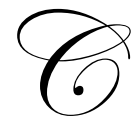

zechoslovakia became a "non-nation" on January 1, 1993. National and ethnic ties did what fifty years of communism attempted to control and suppress; the creation of two separate and distinct nations from what had been one of the only democracies prior to Soviet subjugation. The creation of the Czech and Slovak Republics resulted in two unique and distinct societies that moved in different economic directions. While the Czech Republic prospered within the first six years, the same could not be said for Slovakia. The economic climate and progress within the nation failed to match that of its neighbor. For the first six years, Slovakia's economic growth was stifled due to factors of economic and financial repression. With the beginning of the $21^{\text {st }}$ century, political changes within Slovakia began to transform the society.

As a result of the political changes, financial liberalization began to emerge and, as a result, economic progress. As pronounced were the effects of repression, so too were the effects of liberalization. To truly understand the impact upon the society, the change must be viewed from the viewpoint of foreign direct investment. The factors which limited FDI due to their repressive nature were now being replaced with factors that encouraged and expanded FDI within the Slovak nation. As a result of a complete turnaround transformation, Slovakia is now on a course to sustain and expand economic development through increased FDI. To understand the overall transformation that occurred within the Slovak Republic, one needs to define the factors that create financial repression and the liberalization factors that move an economy in a different direction. The determinants of foreign direct investment (FDI) must be examined to determine if the transition actually contributes or hinders the progress. For the purposes of this paper, one needs to divide the Slovak Republic's transition into distinct periods. Each will offer information to support the premise that FDI is indeed tied to the liberalization of financial policies. The final area of analysis will examine the empirical evidence which ties basic transformation from repression to liberalization to specific governmental actions and the overall economic performance of the society. 


\section{HISTORICAL BACKGROUND AND LITERATURE REVIEW}

The creation of the Slovak Republic actually began in the formation of Czechoslovakia in 1918. For over thirty years, Czechoslovakia existed as a sovereign nation until its assimilation into the Soviet sphere of influence at the end of World War II. For the next forty years, the nation would subscribe to the centralized model of financial planning characteristic of Soviet-style economies. The dissolution of the Soviet Union in the late 1980's ushered a new period of opportunity for the nation. Nationalist trends and identities which had remained suppressed for years resulted in the eventual dissolution of the Czechoslovak nation. What resulted were two nations set on courses 180 degrees apart. The primary challenge facing the new Slovak Republic was the creation of an entirely new central administration, central banking, monetary and tax system (Eperjesivona, 1999, p. 80). While the nation had to build a financial infrastructure, it was also burdened with an inheritance of an industrial complex which was focused on heavy industry which had as its primary product arms production. With a $90 \%$ decline in demand starting before the dissolution and extending three years into independence, the new Slovak Republic faced a serious set of negative factors (Eperjesivona, 1999, p. 81). The study of FDI in Slovakia necessarily involves a comparison with the Czech Republic. Many scholars have also found it fruitful to draw comparisons among the four Central and East European nations, namely, Hungary, Poland, the Czech Republic and Slovakia.

The growing importance of FDI in the automotive industry in the four central European countries namely, the Czech Republic, Hungary, Poland and Slovakia has led to their industrial upgrading (Pavlínek, Domański, and Guzik, 2009). An empirical study of Poland, Hungary, Slovenia, Slovakia and Estonia demonstrates that foreign investors' ownership and control over strategic decisions systematically lead to the respective countries' export intensity (Filatotchev, Stephan, and Jindra, 2008). The speed of integration to the European economic sphere through FDI and international trade has not been able to prevent job losses in the manufacturing industry in the Czech Republic, Hungary, Poland, Slovakia, Slovenia, Lithuania, Bulgaria, and Romania (Onaran, 2008). In the Czech republic and Slovakia, coalitions of social actors have formed as power blocs to attract foreign investors and promoting them in the regions (Drahokoupil, 2008). The effect of productivity is strong in capital-intensive sectors in comparison with labor intensive sectors and the effect of unemployment seems stronger in unskilled sectors than in skilled ones (Onaran and Stockhammer, 2008). Inward FDI tends to have a more dynamic impact upon a region and does not simply result in the industrialization of a few select plants (Pavlínek and Smith, 1998).

\section{FACTORS OF FINANCIAL REPRESSION AND LIBERALIZATION}

Before embarking on a detailed analysis, one must define the factors which characterize both financial repression and liberalization. From a historical perspective, the literature suggests that in the 1970's and into the 1980's most emerging markets had some degree of financial repression (Das, 2003). Financial repression is characterized by four elements. They are controls on interest rates, ability to limit size of bank loans, prohibitions on foreign currency denominated deposits and a dual currency market (Das, 2003). The existence of these characteristics is manifested in a number of policies which could impede economic development and ultimately foreign direct investment. The resulting repressive policies are 1.) control over interest rates on both deposits and loans, 2.) exchange rate controls, 3.) capital flow controls, 4.) directing credit to selected areas, 5.) foreigner's exclusion from domestic equity market participation (Das, 2003) and 60 high reserve requirements.

Further examination of the literature confirms that these are the primary factors at work in an economic environment which is financially repressive. Mezias has identified this category as liability of foreignness - LoF (Ataullah \& Lei, 2004). This phenomenon causes foreign firms to incur costs from which a domestic firm is exempt. The next level is focused on incurring costs to a greater extent or to be denied benefits to which domestic firms are entitled. Factors which support financial repression created the concept of LoF as a method to impede the resource utilization of foreign banks relative to their domestic counterparts. Based upon this assumption, the concept of LoF is a key factor which can impact the evolution of FDI in an emerging economy. As economies develop, the effect of financial repression is replaced through the process of financial liberalization. The timeline of liberalization paralleled the development of emerging markets with the period of 1972 to 1999 showing the greatest activity (Das, 2003). While the removal of repressive measures was slow, it maintained a continuous pace in most countries. In most markets, the transformation of liberalization can be characterized by reforming the banking sector, deregulation of interest rates, opening of the capital accounts, and removal of restrictive measures on domestic 
equity markets. The reform of the banking sector has a number of components. The one with the greatest impact is reducing government interference in lending decisions. This can be accomplished through the true privatization of nationalized banks and the introduction of foreign bank competition.

While the move from a repressive financial environment to one of greater liberalization may have been slow, the overall effects on economic growth were great. Liberalization favorably affects growth by strengthening the size and improving the efficiency of the domestic financial system. It allows domestic firms to access global financial markets. Improvements in the level of corporate governance in the domestic financial systems are also observed. Finally, liberalization promotes foreign competition in the domestic banking and non-banking financial sectors thereby reducing the cost of capital (Das, 2003). Each of these points is extremely important for collectively they will impact the development of foreign direct investment in a country.

\section{DETERMINANTS OF FOREIGN DIRECT INVESTMENT}

The foreign direct investment process can be characterized by a model which accounts for the following elements: market size, proximity to resources, labor costs, transition process, degree of openness and manufacturing sector size (Resmini, 2000). While the model encompasses a number of factors, FDI will occur only if three sets of factors simultaneously exist within a market. The three factors are the presence of ownership-specific advantages, presence of location advantages in both home and host countries, and the presence of superior commercial benefits. Numerous studies have concluded that location determinants are a strong driver of FDI (Witkowska, 2007). The Slovak Republic is part of a group of countries which collectively form the Central and Eastern European Countries (CEEC). Within the CEEC, the main factors driving FDI are the need to secure market access, the timing and form of the privatization process, and the degree of political and economic stability (Resmini, 2000). While these factors point to FDI being dependent upon a specific country, in reality, it is industry specific (Resmini, 2000). Industries in specific countries will attract foreign direct investment when the government begins to transform the economic landscape affecting FDI. The characteristics of foreign investing policies which tend to promote foreign direct investment are rather simple in concept, but may be difficult to implement without a concerted effort on the part of a government. The provision of basic guarantees for foreign investors is key to attracting FDI. The granting of greater privileges to foreign firms than to domestic firms is an inducement which may be viewed as discriminatory by the home firms. Offering protective measures around ownership and implementation of tax incentives complete the set of policies which are used by emerging markets to attract FDI (Witkowska, 2007). It has been stated that FDI is industry-specific and not country specific. In light of this information, how is FDI affected by political stability or the lack thereof? Political stability has a direct link to economic performance, overall growth, behavior of stock markets and foreign exchange markets (Brada, Kutan, \& Yigit, 2006). Each of these metrics are additional key factors in the FDI arena.

The final set of FDI determinants can be classified as macroeconomic factors. The collapse of the BrettonWoods system led to exchange rates which would fluctuate and an overall level of volatility. Exchange rate fluctuation along with several other factors gives rise to the concept of purchasing power parity. The decision to invest foreign capital in an emerging market can be influenced by exchange rate volatility. Empirical evidence exists to suggest that purchasing power parity may not hold across all time periods during which FDI occurs and therefore exchange rate changes can affect the overall competitiveness of industries in different countries (Baniak, Cukrowski, \& Herczynski, 2005). This concept of exchange stability or volatility is a key factor in determining not only the flow of foreign direct investment, but also the type of investors providing the FDI (Borensztein, DeGregorio, \& Lee, 1998).

\section{SLOVAKIA'S PERIODS OF CHANGE}

The first period of change started with the creation of the nation in 1993 and extended to 1998. From the onset, the Slovak Republic was at a great disadvantage when compared to its Czech neighbors due to an economy that was dominated by heavy industry with the primary product being arms production (Meszaros, 1999). In terms of policies and programs, many were holdovers from the era of central planning. The government of this period, known as the Merciar period, attempted to embark on a pattern of change. One of the main thrusts of the transition was the privatization of industry. Merciar's government sought to replace the coupon privatization program that had been 
launched before the break-up with a "non-transparent" program of direct sales to political allies and clients (Fisher, J., \& Haughton, 2007). In this program company managers were allowed to buy majority stakes in corporations at a fraction of their real worth (Meszaros, 1999). By controlling the privatization program, the government was able to solidify important economic alliances that would help them to maintain power.

In the area of financial sector reforms, similar strategies were employed. Partial bank privatization and the resultant politicized lending to political clients undermined the financial sector. In addition tax evasion, social payments and communist-era holdover programs lead to the creation of a fiscal crisis (Eperjesivona, 1999). As a result of these failed programs, FDI and portfolio investors avoided Slovakia making it increasing dependent on foreign loans to finance growth based on credit transfers to key political clients. Such policies were unsustainable and by 1998 the country was facing financial insolvency (Fisher, J., \& Haughton, 2007). The crisis was fueled by four main factors. A severe financial imbalance coupled with a weak banking system set the basis for the problems. The programmatic factors were a surging balance of external debt coupled with the future obligations of the failed privatization program (Fisher, J., \& Haughton, 2007). Beginning in 1998 the Slovak Republic would start to move in a different direction. The election of a new government was the start of the second transition (Meszaros, 1999). Three areas of change would be key to the transformation of the Slovak economy. A program of macroeconomic stabilization tied to trade liberalization would be essential if the country was to move forward. In addition, basic structural changes would be required. The efforts of the macroeconomic stabilization program sought to release and then stabilize prices. This was accomplished through removing price controls, restricting money supply and restraining government spending (Fisher, and Haughton, 2007). The goal of trade liberalization was to increase competition by opening domestic markets to foreign competition, permitting entrepreneurs to engage in trade and the elimination of monopolies. The privatization of banks and other enterprises was only part of the necessary structural changes. In addition, the creation and implementation of an enforceable contract and bankruptcy framework were keys to the overall set of changes (Eperjesivona, 1999).

The three sets of factors were targeted to specific areas of the economy. Those areas included in the second transition period were fiscal policy, taxation, labor and pension reform, investment programs and the justice systems. (Fisher, and Haughton, 2007). Of all the changes during this transition period, reforms to the fiscal and judicial programs were the most significant. Changes in and a restructuring of the overall tax code created an environment which was now more open and friendly to foreign investment (Carstensen and Toubal, 2004). Legislation to protect investments as well as revisions to the commercial and criminal codes aided in transforming the landscape (Bevan and Estrin, 2004). In summation from the period of 2000 to 2005, Slovakia launched a set of economic reforms that limited government and transferred social and economic risk to individuals. In light of these impressive gains, could we have overlooked a key driving force aimed at attracting FDI? During this period, the Slovak Republic was positioning itself for entry into the European Union. While we would argue that the reforms would have occurred independently, the goal to ascend to the EU hastened their acceptance (Bevan and Estrin, 2004). As a result, the government created an environment which was more transparent and operated within a complete and consistent regulatory framework. It is important to note that the changes in corporate governance legislation to meet the requirements of the EU had a dramatic effect on accelerating the rate of FDI in the Slovak Republic.

\section{EMPIRICAL EVIDENCE OF CHANGE}

The removal of financially repressive factors and a replacement with factors focused on liberalization occurred due to the transitions occurring from 1994 to 2004. Throughout the periods of change, the Slovak Republic considered FDI an important source of investment to further expand markets, technology and management techniques (Borensztein, DeGregorio, and Lee, 1998). Until the year 2000, the development of FDI flowing into Slovakia had an upward trend, but its volume and pace lagged far behind the needs of the economy. The abrupt change beginning in 2000 is dramatic. While the data is based upon empirical evidence, one could argue that the policies of transformation focused on the elimination of repression and the liberalization of financial factors aided in the positive growth. Table 1 presents the present status of FDI inflows and stocks as of 2007.

Slovakia's inward FDI performance index has a score of 49 with a potential index of 53 which shows the possibility of room for additional inflow of FDI in many a sector. German automotive multinationals Volkswagen 
and Skoda, US multinational corporations such as IBM, Coca-Cola and Cisco, Tesco and Whirlpool in the tertiary sector, and Allianz, Citigroup and Credit Lyonnais in the financial services industry are all vigorously participating in the market amidst numerous other competitors. Table 2 provides evidence of several state-owned enterprises that may open up for a huge influx of FDI through a systematic privatization.

\begin{tabular}{|c|c|c|c|c|c|}
\hline & $\begin{array}{c}1990 \text { to } 2000 \\
\text { Annual Average }\end{array}$ & 2004 & 2005 & 2006 & 2007 \\
\hline \multicolumn{6}{|l|}{$\begin{array}{l}\text { FDI Flows } \\
\text { (Inward) }\end{array}$} \\
\hline Slovakia & 634 & 3,031 & 2,107 & 4,165 & 3,265 \\
\hline Czech Republic & 2,131 & 4,974 & 11,658 & 6,013 & 9,123 \\
\hline European Union & 209,482 & 214,342 & 498,400 & 562,444 & 804,290 \\
\hline \multicolumn{6}{|l|}{ FDI Stocks } \\
\hline Slovakia & & & & 38,335 & 40,702 \\
\hline Czech Republic & & & & 79,841 & 101,074 \\
\hline European Union & & & & $5,675,258$ & $6,881,625$ \\
\hline
\end{tabular}

\begin{tabular}{|c|c|c|c|}
\hline S. No. & Name of the State Owned Enterprise (SOF) & Industry & $\begin{array}{c}\text { State } \\
\text { Ownership } \\
(\%)\end{array}$ \\
\hline 1 & Slovenská Televizia & Telecom & 100 \\
\hline 2 & Železničná spoločnost' Slovensko, a.s. (ZSSK) & Transport & 100 \\
\hline 3 & Slovak Railways (Železnice Slovenskej Republiky ŽSR) & $\begin{array}{c}\text { Rail } \\
\text { infrastructure } \\
\text { operator }\end{array}$ & 100 \\
\hline 4 & Železničná spoločnost' Cargo Slovakia, a.s. (ZSSK Cargo) & Transport & 100 \\
\hline 5 & Slovenský Plynárenský Priemysel & Utility & 51 \\
\hline 6 & Slovenské elektráme, a.s. & Utility & 34 \\
\hline 7 & Vodohospodárska výstavba, š.p. & Utility & 100 \\
\hline 8 & Press Agency of the Slovak Republic (TASR) & Media & 100 \\
\hline 9 & $\begin{array}{l}\text { Letecké opravovne Trenčin, a.s. (Aircraft Repair Company } \\
\text { Trenčin JSC) }\end{array}$ & $\begin{array}{l}\text { Aircraft } \\
\text { repair }\end{array}$ & 100 \\
\hline 10 & Slovenský letecký inštitút, a.s. & $\begin{array}{l}\text { Military aviation } \\
\text { testing institute }\end{array}$ & 100 \\
\hline 11 & ZTS TEES Martinske strojarne a.s.. & Defense & 100 \\
\hline 12 & Vojenský opravárenský podnik 015 Nováky & Military repairs & 100 \\
\hline 13 & Vojenský opravárenský podnik 027 Trenčin & Military repairs & 100 \\
\hline 14 & LOBB Banská Bystrica a.s. & Defense & 100 \\
\hline 15 & Konstrukta-Defence, a.s. & Defense & 100 \\
\hline 16 & Slovak electricity transmission system, Plc. (SEPS) & Utility & 100 \\
\hline 17 & State Fund for Market Regulation & $\begin{array}{l}\text { Intervention } \\
\text { agency }\end{array}$ & 100 \\
\hline 18 & Slovenská pošta, a. s. (Slovak Post) & Postal & 100 \\
\hline
\end{tabular}




\section{CONCLUSION}

According to the Economic Intelligence Unit's reports, real gross domestic product (GDP) in Slovakia's main export markets will fall in 2009. The GDP growth is expected to slow to 1.5 percent in 2009 as the recession erodes export growth further, but will grow by 2.5 percent in 2010 . The foreign direct investment (FDI) is also likely to decline in 2009, mainly due to the global financial crisis, but it is expected to recover gradually from 2010 . The potentially adverse effects of FDI for regional economic development, such as uneven development, development of a dual economy and failure to develop linkages with local and regional economies, need to be addressed (Pavlínek, 2004). The Slovak Republic was a nation that, from its very start, had to overcome a number of serious economic disadvantages. As an emerging economy, it embodied many factors related to financial repression. Through a series of governments and varying efforts, progress removed the repressive factors and ultimately instituted policies and programs which led to financial liberalization. While one may argue the factors had numerous effects, one of the greatest areas of impact was on foreign direct investment. Empirical evidence suggests the trend in increasing FDI tracks to the liberalization and reform of the Slovak economic environment.

\section{AUTHOR INFORMATION}

Dr. Sivakumar Venkataramany serves as an Associate Professor of Management in the Dauch College of Business \& Economics at Ashland University, Ashland, Ohio where he teaches global management and global finance. Besides teaching commitments abroad, he also serves as an examiner for doctoral theses. He received his MBA, MS and Ph.D. from the University of Miami, Coral Gables, Florida, US. His research interests are risk management in global banks, emerging financial markets and FDI in developing economies.

Paul Miklovich is the Administrative Director of Patient Support Services at the Cleveland Clinic, Cleveland, Ohio. Under his leadership, clinical engineering services were consolidated across twelve hospitals in two states. Paul travels extensively on behalf of the Clinic consulting on various projects and providing support to foreign health agencies. He began his career as a Clinical Engineer with the Veterans Administration Health System. Paul holds a BSME from Ohio State University and graduate degrees from Case Western Reserve University and Ashland University. He also serves as an adjunct faculty in the School of Medicine and Biomedical Engineering at Case Western as well as a guest lecturer at Cuyahoga Community College.

\section{REFERENCES}

1. Ataullah, A., and Lei, H., "Financial Repression and Liability of Foreignness in Developing Countries", Applied Economics Letters, 2004, pp. 545-549.

2. Baniak, Andrzej; Cukrowski, Jacek; Herczyński, Jan, "On the Determinants of Foreign Direct Investment in Transition Economies", Problems of Economic Transition, Jun 2005, Vol. 48 Issue 2, pp. 6-28

3. Bevan, A., and Estrin, S., "The Determinants of foreign direct investment into European Transition Economies", Journal of Comparative Economics, 2004, 32, pp. 775-787.

4. Borensztein, E., DeGregorio, J., \& Lee, J.-W. (1998). How does foreign direct investment affect

5. Brada, J., Kutan, A., \& Yigit, T. (2006). The effects of transition and political instability on

6. Carstensen, K., \& Toubal, F. (2004). Foreign direct investment in Central and Eastern Eurpean countries: a dynamic panel analysis. Journal of Comparative Economics, 32, pp. 3-22.

7. Das, D. K. (2003). Financial liberalisation in the emerging market economies. Journal of Asset Management, 3 (4), pp. 345-359.

8. Drahokoupil, Jan, "The Investment-Promotion Machines: The Politics of Foreign Direct Investment Promotion in Central and Eastern Europe", Europe-Asia Studies, Mar2008, Vol. 60 Issue 2, pp. 197-225

9. "Economic Growth? Journal of International Economics, 45, 115-135.

10. EIU, Outlook for 2009-10: Economic Forecast, Country Report. Slovakia, Mar2009, pp. 5-8

11. Eperjesivona, L. (1999). The Slovak Repuiblic-Back on Track. European Business Journal, pp. 80-87.

12. Filatotchev, Igor; Stephan, Johannes; Jindra, Björn. "Ownership Structure, Strategic Controls and Export Intensity of Foreign-invested Firms in Transition Economies", Journal of International Business Studies, Oct2008, Vol. 39 Issue 7, pp. 1133-1148 
13. Fisher, S., J., G., \& Haughton, T. (2007). Slovakia's Neoliberal Turn. Europe-Asia Studies, 5 (6), pp. $977-$ 998.

14. Mandel, M., \& Tomsik, V. (2008). External Balance in a Transition Economy: The Role of Foreign Direct Investment. Eastern European Economics, 46 (4), pp. 5-26.

15. Meszaros, A.., "Diversgent Neighbors The Czech Republic and Slovakia Since Independence", Harvard International Review, 1999, pp. 30-33.

16. Onaran, Ozlem. "Jobless Growth in the Central and East European Countries: A Country-Specific Panel Data Analysis of the Manufacturing Industry", Eastern European Economics, Jul/Aug2008, Vol. 46 Issue 4, pp. $90-115$

17. Onaran, Özlem; Stockhammer, Engelbert. "The Effect of FDI and Foreign Trade on Wages in the Central and Eastern European Countries in the Post-Transition Era: A Sectoral Analysis for the Manufacturing Industry”. Structural Change \& Economic Dynamics, Mar2008, Vol. 19 Issue 1, pp. 66-80

18. Pavlínek, Petr, "Regional Development Implications of Foreign Direct Investment in Central Europe", European Urban \& Regional Studies, Jan2004, Vol. 11 Issue 1, pp. 47-70

19. Pavlínek, Petr; Domański, Bolesław; Guzik, Robert. "Industrial Upgrading through Foreign Direct Investment in Central European Automotive Manufacturing", European Urban \& Regional Studies, Jan2009, Vol. 16 Issue 1, pp. 43-63

20. Resmini, L. (2000). The determinants of foreign direct investment in the CEECs. Economics of Transition, 8 (3), pp. 665-689

21. Sung, H., \& Lapan, H. (2000). Strategic Foreign Direct Investment and Exchange-Rate Uncertainty. International Economic Review , 41 (2), pp. 411-423

22. Szilagyi, P., Batten, J., \& Fetherson, T. (2003). Disintermediation and the Development of Bond Markets in Emerging Europe. International Journal of the Economics of Business, 10 (1), pp. 67-82

23. Witkowska, J. (2007). Foreign Direct Investment in the Changing Business Environment of the European Union's New Member States. Global Economy Journal , 7 (4), pp. 1-30 
NOTES 